\title{
Chemistry and Architecture of the Mycelial Wall of Agaricus bisporus
}

\author{
By G. O. MICHALENK O*, H. R. HOHL AND DORA RAST \\ Institute of General Botany, University of Zürich, 8006 Zürich, Switzerland
}

(Received 30 May 1975; revised 12 September 1975)

\begin{abstract}
SUMMARY
A purified wall fraction was prepared from the mycelium of Agaricus bisporus. The isolated wall consisted of $43 \%(\mathrm{w} / \mathrm{w})$ chitin, $14 \% \mathrm{KOH}$-soluble glucan, $27 \%$ $\beta$-glucan, $16 \%$ protein and $1.5 \%$ lipid. Traces of mannose and xylose were detected by gas chromatography. The architecture of the wall was investigated with sequential enzyme digestion and electron microscopy. The outer wall surface is covered by a mucilage that is removed by the isolation procedure. The wall fraction could be completely degraded by extraction in warm I $\mathrm{M}-\mathrm{KOH}$ followed by digestion with a mixed $\beta$-glucanase and then chitinase. The outer layer of $\mathrm{KOH}$ soluble glucan is amorphous and of variable thickness. Incubation with glucanase did not change the dimensions of the wall but was necessary before the inner wall was susceptible to attack by chitinase, indicating that $\beta$-glucan does not constitute a separate wall layer but is a matrix associated with the fibrillar chitin. The inner layer presents an even, compact, fibrillar side as the inside surface of the wall, but is looser and uneven outwardly where it interdigitates with the irregular inner surface of the $\mathrm{KOH}$-soluble glucan. Silver hexamide staining showed cystine-containing protein throughout the wall.
\end{abstract}

\section{INTRODUCTION}

The fruit body of the Agaricales is massive, yet mainly consists of relatively undifferentiated hyphal elements similar to the vegetative mycelium, and thus provides an interesting system for studying the mechanisms of hyphal aggregation in morphogenesis. A number of striking correlations between fungal cell form and wall composition, particularly in such phenomena as hyphal-yeast cell type dimorphism, emphasize the importance that wall composition may have in determining differentiation and morphogenesis (Smith \& Galbraith, 1971). The composition and architecture of the hyphal wall is now known in a variety of fungi, but a more or less complete picture is available for only one near relative of the mushrooms, Schizophyllum communc, a member of the Aphyllophorales. We present here a study of the hyphal architecture of the common mushroom, Agaricus bisporus, and compare and relate it to $S$. commune and the existing fragmentary picture in the Agaricales itself.

\section{METHODS}

Culture. Agaricus bisporus (Lange) Sing. fruit bodies, strain A4, were obtained from E. Hauser-Champignonkulturen AG, Gossau, Zürich. To collect spores free of contamination,

\footnotetext{
* Present address: Department of Man-Environment Studies, University of Waterloo, Waterloo, Ontario, Canada.
} 
a method adopted from Stäuble ( 1972) was used. Collecting chambers were constructed from 21 tall-form beakers plugged with half-rolls of cotton wadding into which wire hangers had been inserted. The bottoms of the chambers were covered with small strips of filter paper, and the chambers autoclaved. Unexpanded fruit bodies with pilei 6 to $10 \mathrm{~cm}$ wide and intact annuli were peeled. The annuli and basal parts of the stipes were removed under sterile conditions, and the cleaned fruit bodies were fixed to the hangers of the chambers and left for 2 days. The spores deposited on the paper remain viable for up to 2 years or more when kept in sealed containers at $5{ }^{\circ} \mathrm{C}$. Test tubes with $5 \mathrm{ml}$ of potato broth, prepared according to Gruen ( 1969 ) but with $\mathrm{I} \%$ (w/v) xylose substituted for dextrose, were inoculated with paper strips and incubated for 10 to 15 days at $24{ }^{\circ} \mathrm{C}$ until small tufts of hyphae could be seen. These suspensions of germinated spores were then used to inoculate flasks of defined medium (Treschow, I944; $2 \mathrm{ml}$ inoculum to $100 \mathrm{ml}$ liquid medium in $\mathrm{I} 1$ flasks). Mycelial mats were harvested at 17 to 21 days, before extensive aerial growth had occurred.

Preparation of clean wall fragments. In submerged liquid culture, A. bisporus forms a tough mycelial mat embedded in a jelly-like mass of excreted polysaccharide of undetermined composition (Häsler-Küng, 1974). To increase the rate of hyphal breakage, the mycelium was first ground in liquid nitrogen before disruption in a vibrating mill (E. Bühler, Tübingen, Germany). The optimal conditions for breakage were mycelium, $\mathrm{H}_{2} \mathrm{O}$ and $0.5 \mathrm{~mm}$ diam glass beads in a ratio of $3: 17: 40$ (by wt), to a total volume of not more than $30 \%$ of the container used. The hyphal fragments were then thoroughly washed by the method of Mitchell \& Taylor ( I969), except that there were only three cold washes, and $2 \%$ formic acid was used to avoid excessive protein loss. Clumping of the mycelial fragments and adhesion of broken glass particles to the hyphal walls could not be avoided, necessitating strong agitation during washing. Satisfactory results were obtained by alternating brief periods of sonication with rapid washing in a homogenizer at high speed.

The wash solutions were freeze-dried (after dialysis to remove urea and $\mathrm{NaCl}$ ) and analysed for amino nitrogen, reducing sugar, and $\mathrm{N}$-acetylglucosamine as a check on the removal of wall components. The extent of hyphal breakage and cytoplasmic contamination was checked by light microscopic examination, and finally by electron microscopy. The purified wall fraction was freeze-dried and stored at $-20^{\circ} \mathrm{C}$ under desiccation.

Chemical fractionation and analysis. Freeze-dried purified walls (10 $\mathrm{mg}$ ) were rehydrated overnight, then incubated in $10 \mathrm{ml}$ of I $\mathrm{M}-\mathrm{KOH}$ for $20 \mathrm{~min}$ at $60^{\circ} \mathrm{C}$, washed twice in $\mathrm{I} \mathrm{M}$ $\mathrm{KOH}$ for $5 \mathrm{~min}$, and five times in water. Portions of the treated wall suspension were dried over $\mathrm{P}_{2} \mathrm{O}_{5}$ in vacuo, and the loss in weight determined gravimetrically. The $\mathrm{KOH}$ and wash solutions were combined and the extracted glucan precipitated with 2 vol. of $95 \%$ ethanol. Both supernatant and precipitate were tested for glucose, protein and chitin.

Qualitative sugar analyses were made on $\mathrm{H}_{2} \mathrm{SO}_{4}$ hydrolysates. Walls were first hydrolysed in Io $\mathrm{M}$-acid at $25^{\circ} \mathrm{C}$ for $3 \mathrm{~h}$. The acid was then diluted to $0.5 \mathrm{M}$ and hydrolysis continued in sealed ampoules under nitrogen at $100{ }^{\circ} \mathrm{C}$ for $6 \mathrm{~h}$. Acid was neutralized with $\mathrm{Ba}(\mathrm{OH})_{2}$, $\mathrm{BaSO}_{4}$ was removed by centrifugation, and the supernatant extracted with petroleum ether before de-ionization in a combined Dowex 50W-X8 and Dowex I-X8 column. For gas chromatography, the neutral fraction was dried over $\mathrm{P}_{2} \mathrm{O}_{5}$, dissolved in pyridine, and treated with hexamethyldisilazan and trimethylchlorosilan. Samples were analysed in a Fractovap GI (Carlo Erba) with a column of $5 \%$ SE-30 on Aeropak-30. Total non-nitrogenous carbohydrates were quantitatively estimated either directly with the anthrone test (Chung \& Nickerson, 1954) using frozen suspensions of walls, or with the Nelson-Somogyi test (Nelson, 1944) after hydrolysing the walls in $3 \mathrm{M}^{-\mathrm{H}_{2}} \mathrm{SO}_{4}$ at $105{ }^{\circ} \mathrm{C}$ for $6 \mathrm{~h}$. Results were calculated as glucose equivalents. Glucose was determined on hydrolysates by hexokinase 
(Boehringer, Mannheim, Germany). Chitin was estimated by measuring the glucosamine content of acid hydrolysates with the Elson-Morgan test (Tracey, 1955). Maximum glucosamine release was found with hydrolysis in $6 \mathrm{M}-\mathrm{HCl}(2 \mathrm{mg}$ walls $/ \mathrm{ml})$ at $105{ }^{\circ} \mathrm{C}$ for $14 \mathrm{~h}$. Excess acid was removed by repeated evaporation with water in vacuo. The degree of substrate degradation was estimated with hydrolysates of purified crustacean chitin (Hunsley \& Burnett, 1970).

Total protein was determined by the method of Lowry et al. (I95I) on samples hydrolysed in $6 \mathrm{M}-\mathrm{HCl}(2 \mathrm{mg}$ walls $/ \mathrm{ml})$ at $105^{\circ} \mathrm{C}$ for $6.5 \mathrm{~h}$. The extent of substrate loss was estimated by the parallel hydrolysis of a mixture of 1 part bovine serum albumin in 5 parts cellulose powder. Excess acid was removed in vacuo. The protein content was calculated both by subtracting, from the total Lowry amino nitrogen reading, the amount of absorption due to the hydrolytic products of chitin, as well as by selectively deaminating the amino sugars (Bartnicki-García \& Nickerson, 1962) before amino acid measurement. The values obtained with both methods were almost identical.

Total wall soluble-lipid content was estimated gravimetrically after extraction at $30^{\circ} \mathrm{C}$ for $16 \mathrm{~h}$ in $95 \%$ ethanol-diethyl ether $(1: 1, v / v)$ followed by $16 \mathrm{~h}$ in chloroform-methanol $(3: I, v / v)$.

Enzymic analysis. Various enzymes were screened, both singly and in sequence, for their ability to degrade purified walls or $\mathrm{KOH}$-extracted walls. Those showing some activity were then used for sequential enzymic analyses. Lytic Enzyme LI (BDH), a mixed $\beta$-I,3-glucanase mixture, was used in the sodium acetate-calcium chloride buffer of Marshall (1973) containing mercaptoethanol. The enzyme was dissolved in cold buffer ( $10 \mathrm{mg} / \mathrm{ml}$ ), centrifuged, and $\mathrm{I} \mathrm{ml}$ of enzyme solution added to $10 \mathrm{ml}$ of buffer plus walls ( $\mathrm{r} \mathrm{mg} / \mathrm{ml}$ ). Toluene was added to inhibit bacterial growth and the mixture was incubated at $37^{\circ} \mathrm{C}$, with I ml enzyme solution being added three times at $1.5 \mathrm{~h}$ intervals to maintain the activity of the rather quickly degraded glucanases. Chitinase (Koch-Light) digestion was in a $0^{-1} \mathrm{M}$ sodium phosphate-citrate buffer, $\mathrm{pH} 5.5$, at a ratio of $0.25 \mathrm{mg}$ enzyme $/ \mathrm{ml} \mathrm{buffer,} \mathrm{for} 48 \mathrm{~h}$. Pronase (Koch-Light) was used at $0.5 \mathrm{mg} / \mathrm{ml}$ in $0.1 \mathrm{M}$-phosphate-citrate buffer, $\mathrm{pH} 7.2$, for $48 \mathrm{~h}$. In sequential digestions, the solutions were centrifuged after each incubation, samples of the pellet saved for electron microscopy, and the solutions kept for chemical analysis. The residue was washed thoroughly five times with water before each succeeding digestion. The centrifuged solutions were heated, and trichloroacetic acid was added to pronase solutions to precipitate protein. Glucanase activity was measured in test solutions with the hexokinase test, chitinase by the release of $N$-acetylglucosamine (Kumar \& Hansen, 1972), and pronase by measuring the release of amino acid within ninhydrin (Spies, 1957). All enzyme solutions were examined by electron microscopy to determine what structure, if any, was contributed by the enzymes themselves to the treated wall material.

Electron microscopy. Minced mycelium and suspensions of rehydrated purified wall were fixed in $2.5 \%$ glutaraldehyde in $0.01 \mathrm{M}$-sodium cacodylate buffer $\mathrm{pH} 7.2$ for $30 \mathrm{~min}$. The wall suspensions were then centrifuged and embedded in $1.5 \%(\mathrm{w} / \mathrm{v})$ agar to facilitate handling in subsequent procedures; this step was unnecessary with mycelial preparations because of the gelatinous exudate that bound the hyphae together. Preparations were washed in buffer, fixed in $1 \%(\mathrm{w} / \mathrm{v})$ osmium tetroxide in cacodylate buffer for $90 \mathrm{~min}$, dehydrated in ethanol and propylene oxide, and embedded in Epon 8I2. Thin sections were cut with a diamond knife, stained in $5 \%(\mathrm{w} / \mathrm{v})$ uranyl acetate in $50 \%$ ethanol for $20 \mathrm{~min}$ followed by lead citrate (Reynolds, 1963 ) for 3 to $7 \mathrm{~min}$, and viewed in a Hitachi HS-8 electron microscope.

Electron microscopic visualization of cystine-containing proteins was made with sections 
mounted on carbon-coated Formvar films on gold grids. The silver hexamide method of Swift (1968) was used with the precautions advised by Thompson \& Colvin (1970). Control grids were reduced and alkylated according to Colvin \& Leppard (I97I).

Carbon--platinum replicas were made in a Balzers 360 freeze-etch apparatus using suspensions of wall preparations dried on mica.

Wall thickness was measured with an ocular micrometer on photographic enlargements of micrographs. Care was taken to select sections with sharp, well-focused borders cut close to $90^{\circ}$ to the plane of the walls. With preparations of intact hyphae, the two opposing areas of minimal thickness and sharp definition on either side of the hyphae (the points at which the tangent to the wall was normal to the axis of tilt of the section) were selected. The ribbon-like wall segments seen in sections of purified walls were more problematical. Here regions with sharp edges were selected, and the least width was taken as most nearly approximating to the true width of the wall.

\section{RESULTS}

Cytology

The hyphal walls varied in appearance. The outermost layer, including excreted gelatinous polysaccharide, was discontinuous and loosely structured (Fig. I), and usually stained more densely than the underlying part of the wall. The wall was occasionally split into two, but not at any specific depth. An apparent banding of the wall was frequent, but again irregular: up to three distinct bands were sometimes evident (Fig. 2), but any of these could be the most electron dense, and their thickness, relative to one another, was not constant. The pattern of the bands showed no obvious correlation with age. They were less distinct in purified wall preparations (Fig. 3), although a very thin layer on one side was typically dark. The disorganized outer layer was removed by the isolation procedure.

\section{Wall isolation}

The urea wash residue contained about $2 \%$ reducing sugar and $3 \%$ chitin on a dry wt basis, while the formic acid wash had substantial amounts of amino nitrogen; the amounts of amino acid, $\mathrm{N}$-acetylglucosamine and reducing sugar in the other washes were negligible. To avoid excessive loss of amino acids that might be integral constituents of the wall, the concentration of formic acid was reduced to $2 \%(\mathrm{v} / \mathrm{v})$ and the washing conducted rapidly. Electron microscopic examination of the purified walls (Fig. 3) revealed no cytoplasmic contamination. Because physical abrasion of the hyphal surface was apparent in replica plates of initial preparations, the isolation method as originally used was deemed too harsh. Subsequently, by minimizing the grinding time and the number of repetitions of each washing step (from 5 to 3 , of I min each), preparations were obtained that were free of both abrasion and cytoplasm.

\section{Chemistry and architecture of the wall}

The anthrone procedure, using laminarin as standard, consistently showed that $40 \%$ of the purified wall dry weight was hexose (Table I). The hexokinase test, although more variable, gave a mean value of $4 \mathrm{I} \%$ for glucose. No other sugars were detected by thinlayer chromatography, but with gas chromatography traces of mannose and xylose could be demonstrated, there being 3.5 times more mannose than xylose. The Elson-Morgan test indicated that some $43 \%$ of the wall was chitin. Galactosamine was not detected. Protein determinations ranged from 14.7 to $16.8 \%(\mathrm{w} / \mathrm{w})$ with a mean of $15.6 \%$, either after 

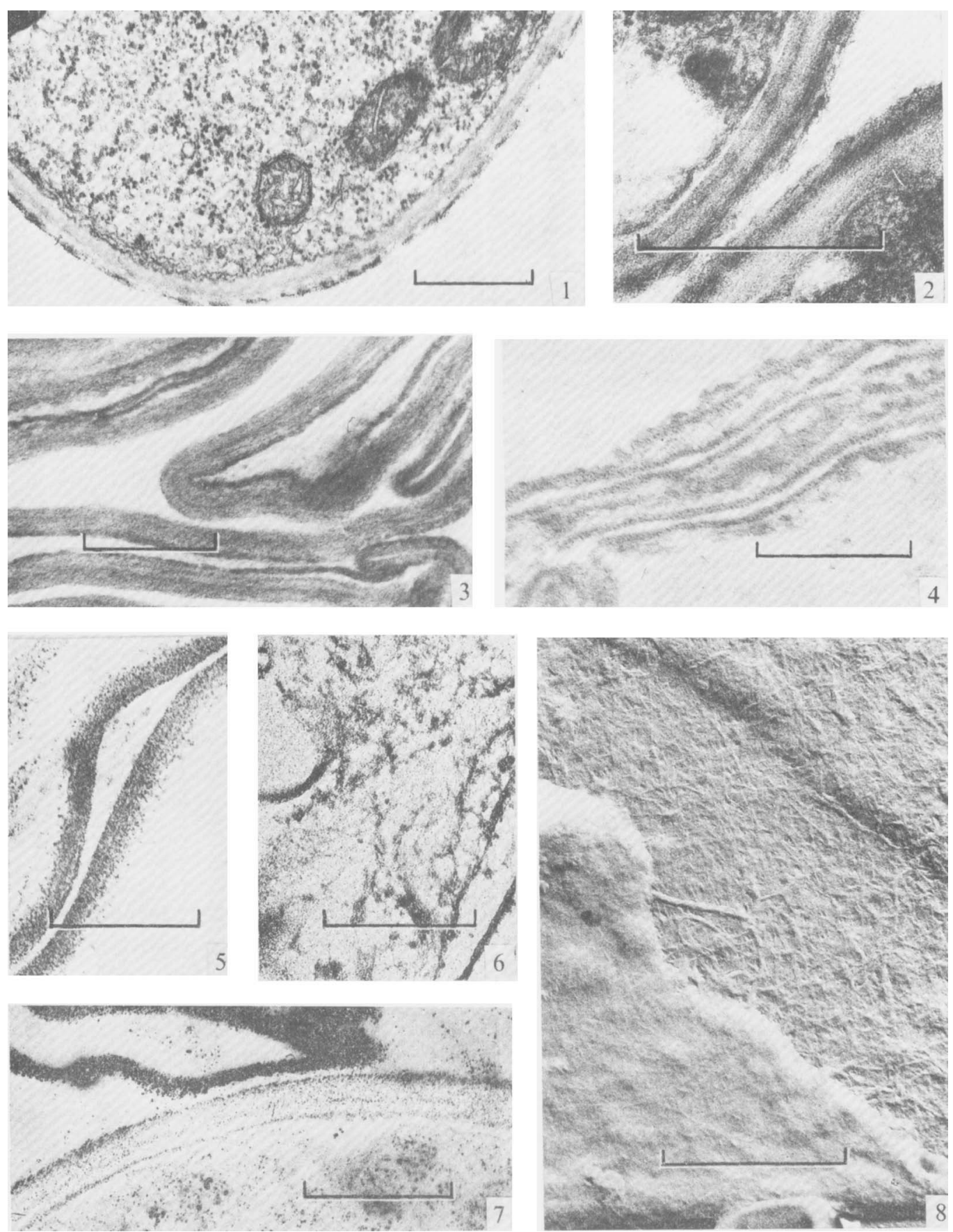

All bar markers $0.5 \mu \mathrm{m}$.

Fig. I. Fixed hyphae of $A$. bisporus. The overlying mucous layer is loose and discontinuous.

Fig. 2. Walls of two adjacent hyphae with different banding patterns.

Fig. 3. Purified wall fragments in near cross-section.

Fig. 4. Walls after $\mathrm{KOH}$ extraction.

Fig. 5. Walls after $\mathrm{KOH}$ extraction followed by $\beta$-glucanase digestion.

Fig. 6. Wall integrity is completely lost after digestion in $\mathrm{KOH}, \beta$-glucanase, and then chitinase.

Fig. 7. Silver hexamide staining. Staining is denser in a thin band in the centre of the wall; the densely-stained structure is a collapsed dead hypha without cytoplasm.

Fig. 8. Replica plate of purified wall preparation. The outer surface of the torn wall is amorphous, while the inner surface is fibrillar. 
Table I. Hyphal wall composition of Agaricus bisporus

Component

Total non-nitrogenous hexose Glucose

Mannose

Xylose

Glucosamine

Protein

Soluble lipid
Method of analysis

Anthrone

Hexokinase

Gas chromatography

Gas chromatography

Elson-Morgan

Lowry

Gravimetric

tr., Trace.

* Average of 5 determinations.
Amount

$(\%, w / w)$

$39 \cdot 9^{*}$

$40 \cdot 7^{*}$

tr.

tr.

$43 \cdot 2^{*}$

$15 \cdot 6^{*}$

I. 6

allowing for colour yielded by hexosamine, or after specific removal of 2-amino nitrogen. A small amount of lipid was detected.

The $\beta$-glucanase preparation hydrolysed $4.5 \%(\mathrm{w} / \mathrm{w})$ of the wall glucan after $48 \mathrm{~h}$ incubation at $\mathrm{pH} 5 \cdot 3$. No $\mathrm{N}$-acetylglucosamine, and only a trace of amino acid was detected in the filtered solution. No more glucose was released by varying the glucanase incubation conditions or by preceding the treatment with incubation in pronase and chitinase. Digestion with $\mathrm{I} \mathrm{M}-\mathrm{KOH}$ at $60{ }^{\circ} \mathrm{C}$ for $20 \mathrm{~min}$ dissolved $\mathrm{I} 6 \%(\mathrm{w} / \mathrm{w})$ of the wall, including $13 \%$ of the protein, $37 \%$ of the hexose, and a trace of $\mathrm{N}$-acetylglucosamine. The remaining wall was $51 \%$ chitin, $27 \%$ glucan, and $16.4 \%$ protein. After $\mathrm{KOH}$ extraction, chitinase alone released only barely measurable amounts of $\mathrm{N}$-acetylglucosamine. Almost complete dissolution of the wall could, however, be achieved when $\mathrm{KOH}$ extraction was followed by digestion in concentrated glucanase solution, and then by a more prolonged incubation in chitinase for $48 \mathrm{~h}$. Pronase did not accelerate digestion.

The inner and outer surfaces of untreated purified walls were dissimilar (Fig. 8). The outer wall surface was smooth and almost featureless, although the outline of underlying fibrils might sometimes be noticed. On the inner wall, randomly orientated fibrils embedded in a matrix could clearly be seen.

Extraction with I M-KOH at $60{ }^{\circ} \mathrm{C}$ removed the overlying amorphous layer (Fig. 9), leaving the two surfaces indistinguishable from one another, except when small areas of amorphous material remained incompletely dissolved on the outer surface. The fibrils were now also more distinct and at least the outer fibrils appeared to have no matrix left between them. Incubation of $\mathrm{KOH}$-treated walls with the glucanase mixture removed more of the interfibrillar matrix. This was especially noticeable at broken wall edges (Fig. I0), where the network of fibrils was often completely free of matrix and short lengths of fibril could be seen that had broken free from the wall residue. Occasionally, long thick fibres could be observed more or less free of the wall (Fig. I I). These occurred most often in groups, and sometimes were twined together in cord-like strands. Subsequent incubation with chitinase resulted in the destruction of wall integrity, leaving a residue of hyphal fragments and a structureless deposit.

Changes in wall thickness after each treatment were measured on enlargements of electronmicrographs of ultra-thin sections. Fixation, dehydration, embedding, and staining of all preparations was identical. Wall thickness was very variable. Regression analysis (Sokal \& Rohlf, 1969) shows that the thickness of untreated walls is positively related to hyphal width $\left(r=0.714 ; r_{0.01(2,26}=0.478\right)$. The thickness of walls after different treatments is shown in Table 2, while micrographs of corresponding thin sections are shown in Figs. I, 3, 4, 5 and 6 . Purified walls were only $60 \%$ as thick as the walls of untreated hyphae. The disorganized 

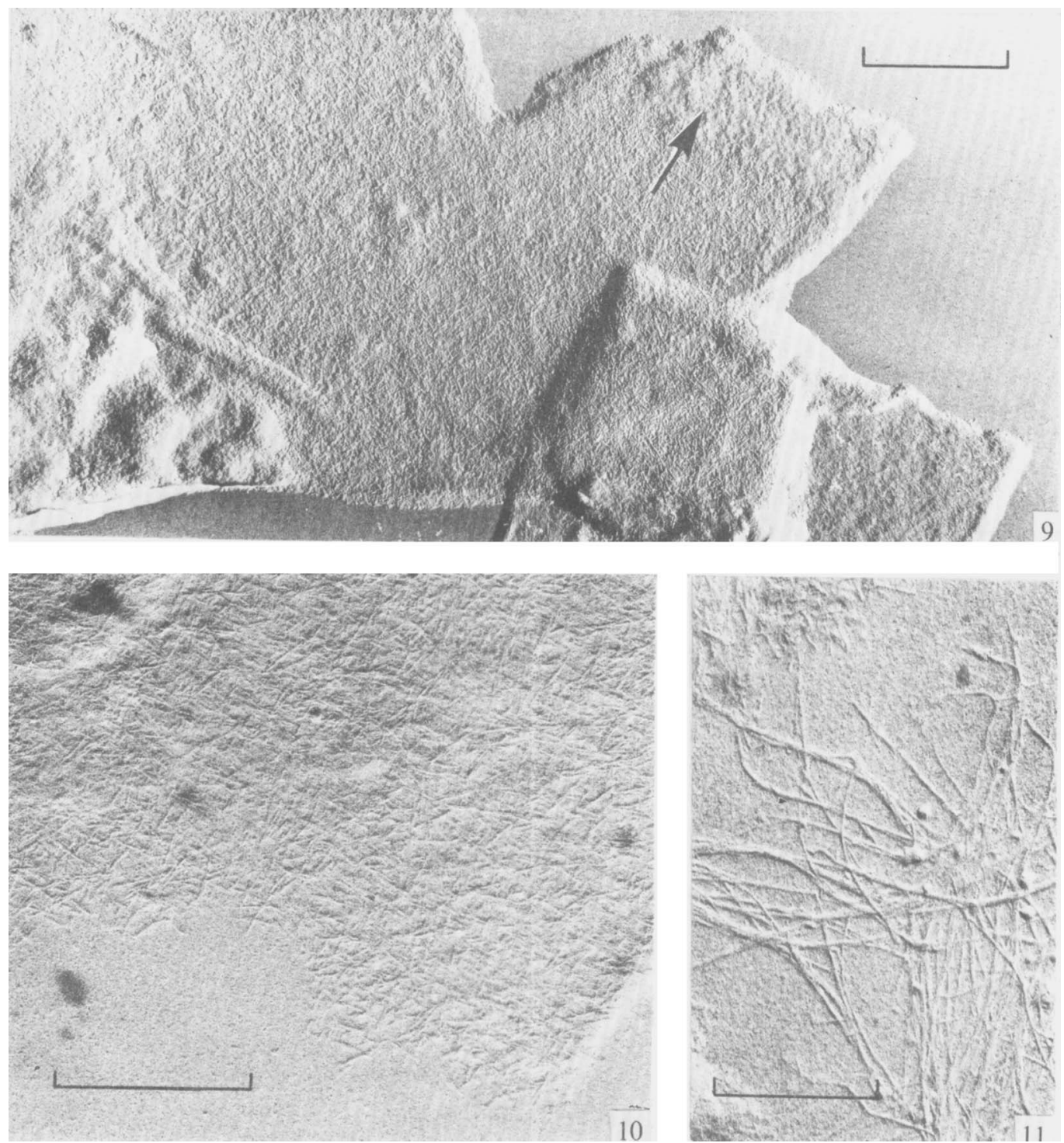

All bar markers $0.5 \mu \mathrm{m}$.

Fig. 9. $\mathrm{KOH}$-extracted wall. The amorphous outer layer is now absent except for a small area at the edge of the hypha (arrow).

Fig. 10. Hypha digested first with $\mathrm{KOH}$ and then $\beta$-glucanase. Much of the matrix has been removed and completely exposed fibrils or loose fibrillar fragments are evident at the edge.

Fig. I I. Long fibrils exposed at edge of broken hypha following digestion with $\beta$-glucanase. Some fibrils appear to be still continuous with the intact wall.

outer layer appeared to have been removed and both surfaces of the purified wall were relatively smooth. Incubation with $\mathrm{KOH}$ reduced the mean minimal thickness of purified walls from $6 \mathrm{r}$ to $49 \mathrm{~nm}$. One surface was now characteristically uneven, sometimes with a series of irregular, slightly darker-staining projections. Digestion of $\mathrm{KOH}$-treated walls with glucanase did not alter the wall dimensions. However, the staining properties of the walls 
Table 2. Hyphal wall thickness after various treatments

$\begin{array}{lcc}\text { Treatment } & \begin{array}{c}\text { No. of walls } \\ \text { measured }\end{array} & \begin{array}{c}\text { Mean minimal } \\ \text { thickness, } \pm \text { S.D. } \\ (\mathrm{nm})\end{array} \\ \text { Untreated } & 38 & \mathrm{I} 00 \pm 27 \\ \text { Isolated wall } & 48 & 6 \mathrm{I} \pm 20 \\ \text { KOH } & 54 & 49 \pm \mathrm{I} 9 \\ \text { KOH }+\beta \text {-I,3-glucanase } & 23 & 50 \pm 13 \\ \text { KOH+ } \beta \text {-I,3-glucanase }+ \text { chitinase } & 25 & 18 \pm 6\end{array}$

changed, and the contrast was far greater than in the diffuse micrographs obtained with identical methods in the previous digestions. The highly contrasted walls sometimes showed banding or striation, often with a smooth, thin, dark line on one surface bordering a thicker light band. The main part of the wall was finely granular, and increasingly loose or porous in appearance toward the other, much less well-defined surface. In some walls, only the granular portion could be seen, although the difference between the one sharp edge and the loose texture at the other surface was particularly noticeable (Fig. 5). After chitinase digestion (Fig. 6), only short lengths of very thin wall residue remained, which were noticeably loose with very fine fibrils when viewed in oblique sections.

The location of cystine-containing proteins in the wall was specifically demonstrated with the silver hexamide method (Fig. 7). The walls of control sections that had been reduced and alkylated before treatment (not shown) were white and contained no more silver than the background, indicating that silver deposition in the wall is not related to ethylenic linkages or aldehyde groups. Cystine protein occurred throughout the wall, but sometimes was slightly more concentrated either at both the wall surfaces and in a thin central stripe, or at the wall edges alone with less staining towards the centre. Walls of hyphae that lacked cytoplasm and were presumably dead, stained very intensely.

\section{DISCUSSION}

The A. bisporus hyphal wall is organized on the basic pattern described in detail for Schizophyllum commune (Hunsley \& Burnett, 1970; Wessels et al., 1972; de Vries \& Wessels, 1973), that is, there is an inner layer composed of chitin microfibrils in a $\beta$-glucan matrix also containing protein, and an outer layer of $\mathrm{KOH}$-soluble $\alpha$-glucan; a layer of $\beta$-glucan mucilage may also be present on the outer surface.

The isolated walls were only $60 \%$ of the thickness of untreated hyphae. This large difference was probably related to both the freeze-drying and rehydration of the isolated wall preparation, and to the removal of the overlying mucilage. $\mathrm{KOH}$ treatment further reduced the thickness of isolated walls by $20 \%$ and it appeared to act on only the outer surface of the isolated wall fragments, leaving it invariably rough, whilst the inner surface remained smooth. The absence of a discrete protein layer in the Agaricus wall is suggested both by the inability of pronase to either accelerate wall dissolution or produce changes in the appearance of the wall surface, and by the staining pattern with silver hexamide. Treatment with $\beta$ glucanase was essential before chitinase could effectively attack the $\mathrm{KOH}$-extracted wall, even though the glucanase treatment did not alter the thickness of the wall. Thus $\beta$-glucan and protein may form the matrix of a fibrillar chitinous layer which on one side forms the compact, inner surface of the wall, but is looser and uneven on the other side, probably interdigitating with the overlying outer $\mathrm{KOH}$-soluble layer. 
Hunsley \& Burnett (1970) proposed that the $S$. commune wall is comprised of discrete layers of $\alpha$-glucan, $\beta$-glucan, protein and chitin, which correspond with bands seen in permanganate-stained preparations. The existence of the distinct protein layer was based on the failure of chitinase to further digest $\mathrm{KOH}$ - and laminarinase-treated walls of living hyphae without an intervening pronase digestion, as well as the increased visualization of the fibrillar chitin layer and a decrease in wall thickness after pronase treatment. Observations by Wessels et al. (1972) support the presence of the outer $\alpha$-glucan layer. However, de Vries \& Wessels (1973) have also shown that protoplasts can be released from $S$. commune by digesting the walls solely with $\alpha$-glucanase and chitinase, the $\beta$-glucan being degraded endogenously. Structurally, the walls of $S$. commune and $A$. bisporus may thus differ most significantly in the degree to which the $\beta$-glucan component may be regarded as a separate wall layer, or merely as a matrix associated with the chitin layer.

Studies of the walls of regenerating protoplasts of Polystictus versicolor (Strunk, 1963; I 969) indicated that a loose network of fine fibrils is first formed to which an overlying layer of amorphous $\mathrm{KOH}$-soluble material is later added. Micrographs of isolated walls of Rhizoctonia solani (=Corticium, Aphyllophorales) presented by Jones et al. (1972) show a granular outer wall surface (despite the insistence of the authors that it is fibrillar), while a typical chitin fibril network retaining the shape of the wall was obtained after a rigorous alkali/acid digestion. The evidence from these organisms also supports the generality of the architectural model of the basidiomycete wall.

The variable banding in glutaraldehyde-osmium tetroxide-fixed $A$. bisporus hyphae can most probably be attributed to factors other than layers of differing components. In an exhaustive study of the walls of Gram-positive bacteria, Millward \& Reaveley (1974) demonstrated that the constant trilamellar density distribution seen after various fixation procedures was genuine, but was related to packing and not the spatial separation of wall components. Such is conceivably the case with the banding in A. bisporus mycelium.

Chemical analysis revealed quantitative differences between $A$. bisporus and $S$. commune walls. The isolated wall of $A$. bisporus contains some 7 to 8 times more chitin and protein than $S$. commune, and correspondingly less glucose (Wessels, 1965). In A. bisporus, 14\% (w/w) of the wall is $\mathrm{KOH}$-soluble glucan, and $27 \%$ insoluble, while the figures for $S$. commune are 33 to $43 \% \mathrm{KOH}$-soluble glucan, depending on the strain, with almost exactly as much insoluble glucan (Wessels, 1965). It is not known how much of these differences can be attributed to the difference in age of the cultures. Sugars other than glucose may constitute up to 10 to $15 \%(\mathrm{w} / \mathrm{w})$ of the total wall polysaccharide of Basidiomycetes, and mannose, xylose, and fructose are almost always present in varying a mounts (O’Brien \& Ralph, I966). Both xylose and mannose were detected in small amounts in A. bisporus; xylose (Wessels et al., I972) and possibly mannose (Ballesta \& Alexander, 1972) are also present in S. commune. Galactose could not be detected in A. bisporus and appears to occur infrequently in basidiomycete walls (Crook \& Johnston, I962; Duff, 1952; O’Brien \& Ralph, I966; Ballesta \& Alexander, I972).

There are few additional reports in the literature for quantitative comparison of the major wall constituents in the Agaricales and Aphyllophorales. Kreger (I954) reported 30 to $35 \%(\mathrm{w} / \mathrm{w})$ chitin in $A$. campestris (somewhat below the $43 \%$ found in $A$. bisporus), plus a 'small amount of an unknown alkali-soluble component' that was undoubtedly $\alpha$-glucan. O'Brien \& Ralph (1966) examined the chitin and glucan content of the alkali-insoluble portion of walls of 14 members of the Polyporaceae and 3 of the Agaricales. The chitin content varied from 26 to $65^{\circ} \%$, and glucan from 22 to $67^{\circ} \%$. In the mushroom Lentinus strigosus, they found $52 \%$ chitin and $28^{\circ}{ }^{\prime}$, glucan in the alkali-insoluble fraction, figures that 


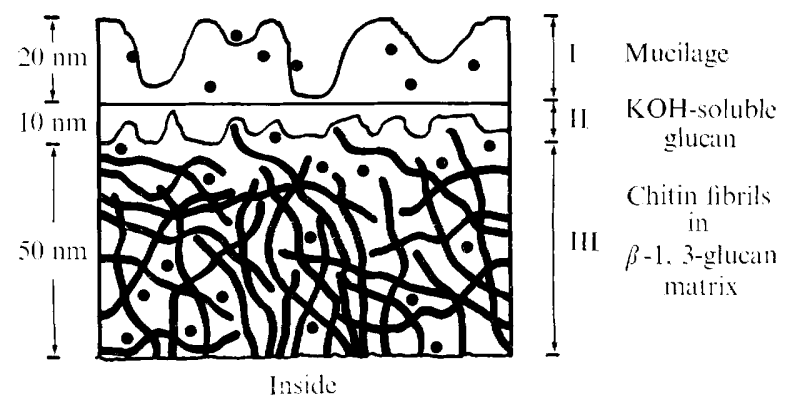

Fig. 12. Diagrammatic model of the hyphal wall of $A$. bisportus. A water-soluble, poorly-organized glucan mucilage (I) lies on the wall proper. Cystine-containing protein occurs throughout the wall. The interface of $\mathrm{KOH}$-soluble glucan (II) and $\beta$-glucan-chitin (III) is irregular, and processes of II interdigitate with the loosely-textured inner side of III. II and III can thus be considered as constituting an entity, with a compositional and structural gradient across it. The concept of completely discrete 'layers' of single components ( $\alpha$-glucan, protein, $\beta$-glucan, chitin) is rejected. , Protein.

are practically identical with $A$. bisporus (5I and $27 \%$ ). There is no information on the protein content of the walls in the Agaricales (except the one presented in this paper).

The presence of $\alpha$-glucan has been demonstrated in the walls of many Polyporaceae (Bacon et al., I968; Carbonell, Kanetsuna \& Gil, I970; Duff, 1952) as well as other members of the Aphyllophorales (Bacon et al., I968; Wessels et al., I972), and there is good evidence that it almost certainly is present in Boletus edulis and Lentinus sp. (Bacon et al., 1968) and A. campestris (Kreger, I954), all members of the Agaricales. Alkali-soluble polysaccharides consisting mostly of glucose are known in an additional number of species (O'Brien \& Ralph, 1966). The presence of $\beta$-glucan has been demonstrated in a number of Basidiomycetes (Bush \& Horisberger, 1972; Hunsley \& Burnett, 1970; Wessels, I965) while the production of $\beta$-I,3-glucanases in many Basidiomycetes, and especially the Polyporaceae, strongly indicates that the $\beta$-glucans in the mycelium may generally represent reserve material for subsequent fruit-body production (Ballesta \& Alexander, 1972; Bush \& Horisberger, I972; Iten \& Matile, I970; Kawai, I973; Reese \& Mandels, I959; Wessels, I966).

The admixture of minor sugar components may provide extra wall resistance to microbial attack, as basidiomycete walls containing higher amounts of mannose and xylose have been found to be more resistant to lysis by Streptomycetes than those with only traces of mannose alone (Ballesta \& Alexander, 1972). The function of overlying mucous layers remains obscure, although they can probably be mobilized during fruiting in at least $S$. commune (Wessels et al., 1972). A similar mucilage is also known in Sclerotium rolfsii (Buck et al., I968).

Our experimental evidence indicates that the A. bisporus hyphal wall is structurally similar to that of $S$. commune. Scattered data from investigations of other Agaricales and Aphyllophorales are in good general agreement with that for A. bisporus, and suggest that it is typical of the higher Basidiomycetes. A diagrammatic model of the A. bisporus wall based on these observations is shown in Fig. I2.

Financial support from the Swiss National Foundation for the Advancement of the Sciences (grant no. 3.I63.73) and the E. Hauser-Champignonkulturen AG, Gossau, Zürich, as well as the advice of Franz Schwegler on electron microscopy, are gratefully acknowledged. 


\section{REFERENCES}

Bacon, J. S. D., Jones, D., Farmer, V. C. \& Webley, D. M. (1968). The occurrence of $\alpha-(1-3)$ glucan in Cryptococcus, Schizosaccharomyces and Polyporus species and its hydrolysis by a Streptomyces culture filtrate lysing cell walls of Cryptococcus. Biochimica et biophysica acta 158, 313-315.

Ballesta, J.-P. G. \& Alexander, M. (1972). Susceptibility of several Basidiomycetes to microbial lysis. Transactions of the British Mycological Society 58, $48 \mathrm{I}-487$.

Bartnicki-García, S. \& Nickerson, W. J. (1962). Isolation, composition, and structure of cell walls of filamentous and yeast-like forms of Mucor rouxii. Biochimica et biophysica acta 58, 102-1 19.

Buck, K. W., Chen, A. W., Dickerson, A. G. \& Chain, E. B. (1968). Formation and structure of extracellular glucans produced by Claviceps species. Journal of General Microbiology 51, 337-352.

Bush, D. A. \& Horisberger, M. (1972). Structure of a $\beta$-D-glucan from the mycelial wall of Basidiomycete QM 806. Carbohydrate Research 22, 361-367.

Carbonell, L. M., Kanetsuna, F. \& Gil, F. (1970). Chemical morphology of glucan and chitin in the cell wall of the yeast phase of Paracoccidioides hrasiliensis. Journal of Bacteriology ror, 636-642.

Chung, C. W. \& Nickerson, W. J. ( 1 954). Polysaccharide syntheses in growing yeasts. Journal of Biological Chemistry 208, 395-407.

Colvin, J. R. \& Leppard, G. G. (197I). The non-uniform distribution of proteins in plant cell walls. Journal de Microscopie II, 285-298.

Crook, E. M. \& Johnston, I. R. (I962). The qualitative analysis of the cell walls of selected species of fungi. Biochemical Journal 83, 325-33I.

Duff, R. B. (1952). The constitution of a glucosan from the fungus Polyporus betulinus. Journal of the Chemical Society 2592-2594.

Gruen, H. E. (1969). Growth and rotation of Flammulina velutipes fruit bodies and the dependence of stipe elongation on the cap. Mycologia 6r, 149 166.

Häsler-KüNG, D. (1974). Die Phenoloxydaxen von Agaricus bisporus. Ph.D. dissertation, University of Zürich.

Hunsley, D. \& Burnett, J. H. (1970). The ultrastructural architecture of the walls of some hyphal fungi. Journal of General Microbiology 62, 203218.

Itr: , W. \& Matile, P. (1970). Role of chitinase and other lysosomal enzymes of Coprinus lagopus in the autolysis of fruiting bodies. Journal of Gieneral Microbiology 6r, 30 I-309.

Jones, D., FArmer, V. C., BaCon, J. S. D. \& Wilson, M. J. (1972). Comparison of ultrastructure and chemical components of cell walls of certain plant pathogenic fungi. Transactions of the British Mycological Society 59, $1 \mathrm{I}-23$.

Kawal, M. (1973). Productivity of $\beta$-I,3-glucanase, chitinolytic, and yeast cell lytic enzymes among the Basidiomycetes. Journal of the Agricultural Chemical Society of Japan 47, 473-477.

KREGER, D. R. (1954). Observations on cell walls of yeasts and some other fungi by X-ray diffraction and solubility tests. Biochimica et biophysica acta $\mathbf{1 3}, \mathbf{I}-9$.

Kumar, S. \& HANSEN, P. M. T. (1972). New reaction mixture for spectrophotometric determination of Nacetylhexosamines. Analytical Chemistry 44, 398-400.

Lowry, O. H., Rosebrough, N. J., Farr, A. L. \& Randall, R. J. (I95I). Protein measurement with the Folin phenol reagent. Journal of Biological Chemistry 193, 265-275.

Marshall, J. J. (1973). Behavior of $\beta$-glucan hydrolases on jon-exchangers. Analytical Biochemistry 53, I 19 I $\cdots$ I 98.

Millward, G. R. \& Reaveley, D. A. (1974). Electron microscope observations on the cell walls of some Gram-positive bacteria. Journal of Ultrastructure Research 46, 309-326.

Mitchell, A. D. \& TAYlor, I. E. P. (1969). Cell wall proteins of Aspergillus niger and Chaetomium globosum. Journal of General Microbiology 59, $103-109$.

Nelson, N. (1944). A photometric adaptation of the Somogyi method for the determination of glucose. Journal of Biological Chemistry $\mathbf{5 3}, 375-380$.

O'Brien, R. W. \& RALPH, B. J. (1966). The cell wall composition and taxonomy of some Basidiomycetes and Ascomycetes. Annals of Botany 30,831 843 .

RFESE, E. T. \& MANDELS, M. (1959). $\beta$-D-I,3 glucanases in fungi. Canadian Journal of Microbiology 5, $173-$ 185.

REYNOLDS, E. S. (1963). The use of lead citrate at high $\mathrm{pH}$ as an electron-opaque stain in electron microscopy. Journal of Cell Biology 17, 208-212.

Smith, J. E. \& Galbraith, J. C. ( I971). Biochemical and physiological aspects of differentiation in the fungi. In Advances in Microbial Physiology, vol. 5, pp. 45-1 34. Edited by A. H. Rose and J. F. Wilkinson. New York: Academic Press.

Sokal, R. R. \& Rohlf, F. J. (1969). Biometry. San Francisco: W. H. Freeman.

SPIES, J. R. ( 1 957). Colorimetric procedures for amino acids. In Methods in Enzymology, vol. 3, pp. 467-477. Edited by S. P. Colowick and N. O. Kaplan. New York: Academic Press. 
STÄUBLE, E. J. (1972). Vorkommen und Stoffwechsel leichtflüchtiger Substanzen von bekannter oder vermuteter physiologischer Wirksamkeit in Agaricus bisporus. Ph.D. dissertation, University of Zürich.

Strunk, C. (1963). Ueber die Substruktur der Hyphenspitzen von Polystictus versicolor. Zeitschrift für allgemeine Mikrobiologie 3, 265-274.

StRUNK, C. (1969). Licht- und elektronenmikroskopische Untersuchungen an regenerierenden Protoplasten von Polystictus versicolor. Zeitschrift für allgemeine Mikrobiologie 9, 205-216.

SWIFT, J. A. (1968). The electron-histochemistry of cystine-containing proteins in thin transverse sections of human hair. Journal of the Royal Microscopical Society 88, 449-460.

Thompson, E. \& Colvin, J. R. (1970). Electron-cytochemical localization of cystine in plant cell walls. Journal of Microscopy 9I, 87-98.

Tracey, M. V. (1955). Chitin. In Moderne Methoden der Pflanzenanalyse, vol. 2, pp. 264-274. Edited by K. Paech and M. V. Tracey. Berlin, Göttingen, Heidelberg: Springer Verlag.

TRESCHOw, C. (1944). Nutrition of the cultivated mushroom. Dansk botanisk Arkiv II, I-I80.

DE VRIES, O. M. H. \& Wessels, J. G. H. (1973). Release of protoplasts from Schizophyllum commune by combined action of purified $\alpha-\mathrm{I}, 3$-glucanase and chitinase derived from Trichoderma viride. Journal of General Microbiology 76, 319-330.

Wessels, J. G. H. (1965). Morphogenesis and biochemical processes in Schizophyllum commune. Wentia $\mathbf{1 3}$, I-II3.

Wessels, J. G. H. (1966). Control of cell-wall glucan degradation during development in Schizophyllum. commune. Antonie van Leeuwenhoek 32, 34I-355.

Wessels, J. G. H., Kreger, D. R., Marchant, R., Regensburg, B. A. \& de Vries, O. M. H. (I972). Chemical and morphological characterization of the hyphal wall surface of the basidiomycete Schizophyllum commune. Biochimica et biophysica acta 273, 346-358. 